\title{
The Etiology of Acute Kidney Injury in Patient with Solid Tumor
}

\section{Solid Tümörlü Hastalarda Böbrek Yetmezliği Nedenleri}

\author{
İbrahim Yıldırım, Esra Durmuşoğlu \\ Sağlık Bilimleri Üniversitesi Tıp Fakültesi, Dr. Abdurrahman Yurtaslan Ankara Onkoloji Suam, İç Hastalıkları \\ Ana Bilim Dall.
}

Dergiye Ulaşma Tarihi: 31.05.2020 Dergiye Kabul Tarihi: 03.06.2020 Doi: 10.5505/aot.2020.42275

\section{ÖZET}

GİİŞ ve AMAÇ: Kanserli hastalarda tümörün kendisine ait ve tedavi ilişkili böbrek yetmezliği gelişebilmektedir. Onkolojik hasta popülasyonunda güncel sınıflama kriterleri ile akut böbrek yetmezliği epidemiyolojine ilişkin düzenli ve sistematik bilgilere ihtiyaç vardır. Bu çalışma kanser hastalarında gelişen böbrek yetmezliklerini etiyolojilerine göre sınıflamak ve risk gruplarını belirlemek için planlanmıştır.

YÖNTEM ve GEREÇLER: Çalışmaya onkoloji servisine herhangi bir nedenle yatmış ve böbrek yetmezliği tespit edilmiş 100 hasta dahil edildi. Hastaların verileri retrospektif olarak incelendi. Böbrek yetmezliği varlığ RIFLEAKIN kriterlerine göre belirlendi ve hastalar prerenal, renal ve postrenal böbrek yetmezliği gruplarına ayrıldı. Eşik eden hastalıklar ve böbrek yetmezliğinin spesifik nedenleri bu üç grup baz alınarak chi square istatistiksel yöntemi ile karşılaştırıldı.

BULGULAR: Solid tümörlü hastalarda en sık böbrek yetmezliği tipi prerenal nedenlere bağlıydı (\%55). Prerenal böbrek yetmezliğinde en sık spesifik neden oral alım azlığı ve gastrointestinal kayıptı. Prerenal, renal ve postrenal böbrek yetmezlik grupları arasında yaş ortalamaları $(\mathrm{p}=0.256)$, cins $(\mathrm{p}=0.259)$, diyabetes mellitus $(\mathrm{p}=0.739)$, hipertansiyon $(p=0.789)$ sigara içim $(p=0.945)$ ve kemoterapötik ajan kullanıp kullanmama $(p=0.339)$ sıklı̆̆ açısından önemli bir farklılık tespit edilmedi. Bu popülasyonda iskemik akut tubüler nekroz sıklığında bariz bir artış gözlendi.

TARTIŞMA ve SONUÇ: Kanserli hastalarda böbrek yetmezliği gelişim nedenleri farklılık gösterebilir. Onkolojik hasta popülasyonunda bu nedenlerin iyi dökümente edilmesi, kanserli hastaların sağkalım sürelerini uzatabilir. Gelişmekte olan ülkelerdeki kanserli tüm hastalarda, böbrek yetmezliği etiyolojisini güncel bilgilerle değerlendirecek çok merkezli prospektif çalışmalara ihtiyaç vardır.

Anahtar Kelimeler: akut böbrek yetmezliği, kemoterapi, kanser

\begin{abstract}
INTRODUCTION: The aim of this study is to evaluate the etiology of renal failure in patients with solid tumor. METHODS: The study was included 100 patients with acute renal failure. These patients were selected among hospitalized patients with solid tumor in Dr. Abdurrahman Yurtaslan Ankara Oncology Education and Research Hospital. The data of these patients were analyzed retrospectively. The presence of acute kidney injury was determined according to RIFLE-AKIN criteria. The patients were retrospectively classified into the following 3 groups: Prerenal, renal and postrenal acute kidney injury (AKI) groups. In these groups, specific causes of renal failure and comorbidities such as diabetes, coronary arteria disease etc. were compared using the chi square statistical analyze.

RESULTS: The most common type of renal failure in patients with solid tumor was prerenal acute kidney injury (\%55). The most common specific cause in all groups with prerenal AKI was inadequate oral intake and gastrointestinal loss. No significant difference was detected in terms of the average age $(\mathrm{p}=0.256)$ and in terms of frequency of sex, diabetes mellitus, hypertension, smoking, whether chemotherapeutic agents in three groups $(p=0.259, p=0.739, p=0.789, p=0.945, p=0.339)$. There was a marked increase in the frequency of ischemic acute tubular necrosis in the study population.

DISCUSSION AND CONCLUSION: The causes of acute renal failure may differ from actuarial estimates in patients with cancer. Complete documentation of these causes in this population with tumor may increase surveys of these patients. In developing countries, multicenter prospective trials are needed to evaluate the etiology of all renal failure in this population.
\end{abstract}

Keywords: acute kidney injury, chemotherapy, cancer

\section{Gİiş̧}

Günümüzde kanser ilişkili ölüm oranları, yeni ilaçların kullanıma girmesiyle giderek azalmaktadır. Hasta için en uygun ve en az zarar verici etkiye sahip yaklaşımlarla tedaviye olan hasta uyumu eskiye nazaran artmaktadır. Vasküler endotelyal büyüme faktör inhibitörleri 
gibi hedefe yönelik ajanların da kanser kemoterapisine eklenmesi, kanserle mücadeleye yeni bir boyut kazandırmıştır. Benzer olumlu gelişmeler kemoterapötik ilaçların bulantı, kusma gibi diğer sistemler üzerinde istenmeyen etkilerin azaltılması alanında da olmuştur. $\mathrm{Bu}$ olumlu gelişmelerin yanı sıra tetkik ve tedavi sırasında kullanılan ilaçların hastalar üzerindeki olumsuz etkileri halen devam etmektedir.

Hasta sağkalımı açısından en önemli tedavi ilişkili- yan etkilerden biri kanserli hastalarda böbrek yetmezliği gelişimidir. Çoğu kanser tiplerinin ileri yaş hastalarında görülmesi de böbrek yetmezliği gelişimini kolaylaştıran bir etkendir. Maligniteli hastalar aynı anda birçok sistemle ilişkili sorunları barındırabilir ve bu hastalarda böbrek yetmezliğinin farklı sebepleri olabilir (1). İntravasküler volümün azalmas1, kemoterapotik ilaçlarla beraber analjezik gibi diğer nefrotoksik ajanların kullanılması, idrar yolu obstrüksiyonları, kanserin kendisine ya da diğer komorbit hastalıklara bağlı böbrek tutulumları böbrek yetmezliği gelişimine zemin hazırlamaktadır. Hastaların yaşlarının ileri olması, daha önceden böbrek hastalığı bulunması ilave risk faktörleri arasındadir (1).

Genel popülasyonda böbrek yetmezliği nedenleri iyi dökümente edilmiştir ve gelişmekte olan ülkelerde en sik etken olarak prerenal faktörler gösterilmiştir (2). Hastaneye yatan tüm hastalar için $\mathrm{ABY}$ insidans $\% 1,9$ olarak bildirilmiştir (3). ABY olan çoğu hastada da sepsis ve böbrek dişında multiorgan tutulumu yapan sistemik bir problem rapor edilmektedir. ABY gelişen hastaların $\% 7,5$ 'unda renal replasman ihtiyacı olmaktadır ve $\mathrm{ABY}$ gelişen hastalarda mortalite oran $1 \% 2,3$ olarak hesaplanmıştır (3). Son zamanlarda yapılan diğer araştırmalarda serum kreatinin düzeyindeki $\quad 0,3 \mathrm{mg} / \mathrm{dl}$ 'lik artışların bile düzeltilmiş mortalite riskinde önemli artışlara yol açtığ 1 vurgulanmaktadır (4).

Onkolojik hasta popülasyonunda ise ABY epidemiyolojisine ilişkin daha düzenli ve sistematik bilgilere ihtiyaç vardır. Bu hastalarda sitotoksik ilaçlara bağlı nefrotoksisite önemli bir böbrek yetmezliği nedeni gibi gözükse de böbrek yetmezliğinin diğer nedenleri çok irdelenmemiştir ve yeni kemoterapötik ajanların böbrek yetmezliğine etkisi de az bilinmektedir. Bu çalışma, solid organ kanserli ve tıbbi onkoloji takipli hastalarda böbrek yetmezliği gelişme sıklığı, şiddeti, böbrek yetmezliği gelişim nedenleri ve böbrek yetmezliğinin akibetinin araştırılması için tasarlanmıştır.

\section{YÖNTEM VE GEREÇLER}

Çalışma 01.04.2019-27.12.2019 tarihleri arasında Sağllk Bilimleri Üniversitesi Dr. Abdurrahman Yurtaslan Ankara Onkoloji Sağlık Uygulama ve Araştırma Merkezi İç Hastalıkları Tibbi Onkoloji servisine herhangi bir nedenle yatırılan kanser hastalarının verileri retrospektif incelenerek yapild1. Kontrollerde serum kreatinin değeri bazal değerinden 0,3 $\mathrm{mg} / \mathrm{dl}$ veya daha fazla yükselen hastalar akut böbrek yetmezliği kabul edilerek çalışmaya dahil edildi. Çalışmaya alınan hastaların tüm hastane başvuru kayıtları, ilk teşhis ve tedavi zamanına kadar geriye dönük olarak incelendi. Böbrek yetmezliği nedeni tam olarak belirlenemeyen hastalar çalışma dışı bırakıldı. Hastaların yaşı, cinsiyeti, onkoloji bölümüne başvuru gerekçeleri, tanıları, komorbit hastalıkları, tedavileri, serum kreatinin değerleri, tam idrar analizi, renal ultrason raporlar1 ile kemoterapi kür ve tarihleri, hospitalizasyon nedenleri kaydedildi.

Hastalar böbrek yetmezliği gelişim nedenlerine göre; prerenal, renal ve postrenal olmak üzere 3 alt gruba ayrıldı. Böbrek yetmezliği evrelemesi için DOQI (Dialysis Outcome Qualty Index) siniflandirmas1 kullanıldı. Böbrek yetmezliği gelişen kanser hastaları, kolorektal kanserler, meme kanserleri gibi tümörün orjin aldığı dokuya göre gruplara ayrıldı ve bu gruplarda böbrek yetmezlik nedenleri incelendi. Yine bu hastalar aldikları kemoterapötik ilaçlara göre nefrotoksik olduğu bilinen kemoterapötik kullanan ve nefrotoksik olmayan ilaçları kullananlar ve henüz kemoterapi almamış olanlar diye üç gruba bölündü ve tedavi ajanlarının hangi türden böbrek yetmezliği yaptığına bakıldı.

Hastaların maligniteye yönelik tedavi alma durumlar1 ise; tan1 konulduktan sonra kemoterapi, radyoterapi veya hedefe yönelik ajan kullanıp da tedavisi 3 aydan uzun süre önce kesilenler "önceden tedavi almış olanlar", halen kemoterapisi devam ederken böbrek yetmezliği gelişenler "aktif kemoterapi alanlar" ve henüz kemoterapi ya da radyoterapi almamış olanlar ise "önceden tedavi almamış olanlar" şeklinde siniflandırıldı. 


\section{İstatistiksel Yöntem}

İki grup arasındaki farkl1lıklar sürekli değişkenlerde; Mann-Whitney U Testi, kategorik değişkenlerde ise Ki-kare testi ile değerlendirildi. $\mathrm{P}<0.05$ 'ten küçük değerler istatistiksel olarak anlamlı kabul edildi. Tüm analizler SPSS yazılımı ile yapıldı (Versiyon 23.0).

\section{SONUÇLAR}

Çalışma tıbbi onkoloji polikliniklerine başvuran toplam 1675 hastanın verileri incelenerek böbrek yetmezliği geliştiği saptanan 100 hasta ile tamamland.

Böbrek yetmezliği gelișen bu popülasyonda en sik erkeklerde sirasıyla akciğer, mide, kolon, kadınlarda ise sirasıyla meme, over ve kolon kanseri vardı. Dağılımlar şekil 1 de gösterilmiş, sıklıklar ise tablo 1 de verilmiştir. Kemik ve bağ doku tümörleri, mesane tümörleri, nöroendokrin tümörleri, primeri bilinmeyen tümörler, baş, boyun ve beyin tümörleri, mezotelyama sayıca az olduğu için tabloda gösterilmemiş ve istatistiksel değerlendirilmeye alınmamıştır.

Hastaların yaş ortalaması $60,89( \pm 13,018)$ idi ve 74 tanesi erkek (\%74), 26 tanesi kadındı (\%26).

Çalışmaya dahil edilen kanser hastalarının 55 tanesinde (\%55) prerenal nedenlere bağl1, 37 (\%37) tanesinde renal nedenlere bağl1, $8(\% 8)$ tanesinde de postrenal nedenlere bağlı böbrek yetmezliği gelişmişti. Yaş ortalamaları açısından bu üç grup arasında bir fark yoktu $(\mathrm{p}=0.256)$, cins açısından da anlamlı bir farklı1ığa rastlanmadı $(\mathrm{p}=0.259)$. Katılımcıların 23 tanesinde diyabetes mellitus (DM), 36 tanesinde hipertansiyon (HT), 20 tanesinde koroner arter hastalığı (KAH) öyküsü, 47 tanesinde sigara içimi öyküsü vardı. 13 tane hasta ise hastalığın başlamasından en az 5 yıl önce sigara içmesini bırakmıştı. Böbrek yetmezliği alt tipine göre prerenal, renal yada postrenal böbrek yetmezliği gelişen gruplarda; DM ( $\mathrm{p}=0.739)$, HT $(\mathrm{p}=0.789)$, sigara içimi $(\mathrm{p}=0.945)$, önceden böbrek yetmezliğ $\mathrm{i}$ $(\mathrm{p}=0 ., 735)$, ultrason veya tomografi görüntüleme tetkiklerinde renal parankimal hastalık $(\mathrm{p}=0.432)$ ve nefrotoksik olduğu bilinen kemoterapatik ajan kullanma $(\mathrm{p}=0.339)$ sıklığı açısından önemli bir farklılık yoktu.
Akciğer, meme, over, mide ve kolorektal kanserli hastalarda prerenal, renal ya da postrenal akut böbrek yetmezliği (ABY) gelişme oranları karşılaştırıldı. Sıklık açısından bu kanser grupları arasında bir fark saptanmadı $(\mathrm{p}=0,562)$. Bu oranlar tablo 2'de gösterilmiştir. Çalışma popülasyonundaki kolorektal, pankreas, meme ve over kanserli hastaların hiçbirinde postrenal ABY gözlenmedi. Renal nedenler en sık diğer başlığı altında kalan primeri bilinmeyen kanserler, mesane, kemik ve bağ dokusundan orjin alan gibi kanserlerde gözlendi. Ancak bu hastaların sayıları çok düşük olduğu için istatistiksel olarak bir analiz yapilmadi.

22 hastada henüz bir kemoterapi başlanmadan böbrek yetmezliği tespit edildi. Tedavi planlanmış ama henüz kemoterapi başlanmamış hastalar ile önceden kemoterapi almış hastalar arasında böbrek yetmezliği gelişim tipi açısından bir fark tespit edilmedi ( $\mathrm{p}=0.097)$.

Böbrek yetmezliği nedeniyle diyaliz ihtiyacı olan hasta sayısı üç taneydi. İki tanesinde kalıcı diyaliz ihtiyacı olmamıştı. Hemodiyalize devam eden bir hasta vard 10 da hastalığın erken döneminde diyaliz hastası olmuştu. Prerenal böbrek yetmezliklerinin tamamı düzelmişti. Çalışma hastalarının 12 tanesinin eks olduğu gözlendi. Bunlardan 6 tanesi prerenal, 6 tanesi de renal nedenlerle böbrek yetmezliğine girmişti. Sepsis nedeni ile ölen 4 hastada böbrek yetmezliğinin evresi daha ileri idi.

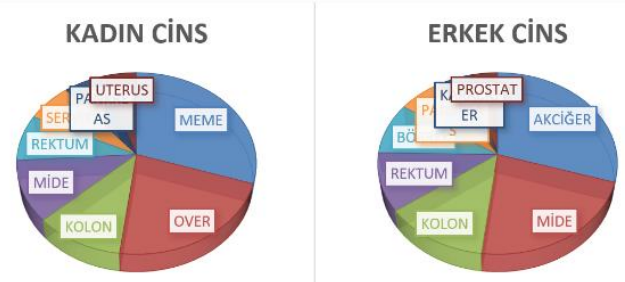

Şekil 1: Böbrek yetmezliği gelişen solid organ tümörlü hastalardaki tümör dağılım grafiği

Tablo 1: Böbrek yetmezliği gelişen solid organ tümörlü hastalardaki tümör dağılım yüzdeleri

\begin{tabular}{lclc}
\hline \multicolumn{1}{c}{ KADIN $(\mathrm{n}=26)$} & SIKLIK $(\%)$ & \multicolumn{1}{c}{ ERKEK (n=74) } & SIKLIK (\%) \\
\hline Meme malign neoplazm & 22 & Akciğer malign neoplazmı & 23 \\
\hline Over malign neoplazm & 16 & Mide malign neoplazmı & 17 \\
\hline Kolon malign neoplazmı & 8 & Kolon malign neoplazmı & 10 \\
\hline Mide malign neoplazmı & 8 & Rektum malign neoplazmı & 8 \\
\hline Rektum malign neoplazmı & 6 & Böbrek malign neoplazmı & 7 \\
\hline Serviks malign neoplazmı & 5 & Pankreas malign neoplazmı & 5 \\
\hline Pankreas malign neoplazmı & 4 & Karaciğer sekonder neoplazmı & 4 \\
\hline Uteri malign neoplazmı & 4 & Prostat malign neoplazmı & 3 \\
\hline
\end{tabular}


Tablo 2: S1k görülen kanserlerde gelişen böbrek yetmezliği tipi oranları

\begin{tabular}{lccccccc}
\hline & AKCIĞER & Mide & \multicolumn{2}{l}{ KOLON PANKREAS } & REKTUM & MEME & OVER \\
\hline PRERENAL (\%) & 76 & 56 & 73 & 63 & 57 & 80 & 100 \\
\hline RENAL $(\%)$ & 18 & 31 & 27 & 37 & 43 & 20 & 0 \\
\hline POSTRENAL (\%) & 6 & 13 & 0 & 0 & 0 & 0 & 0 \\
\hline Toplam Hasta (n) & 17 & 16 & 11 & 8 & 7 & 5 & 3 \\
\hline
\end{tabular}

Tablo 3: Solit organ tümörlü hastalarda akut böbrek yetmezliği nedenleri

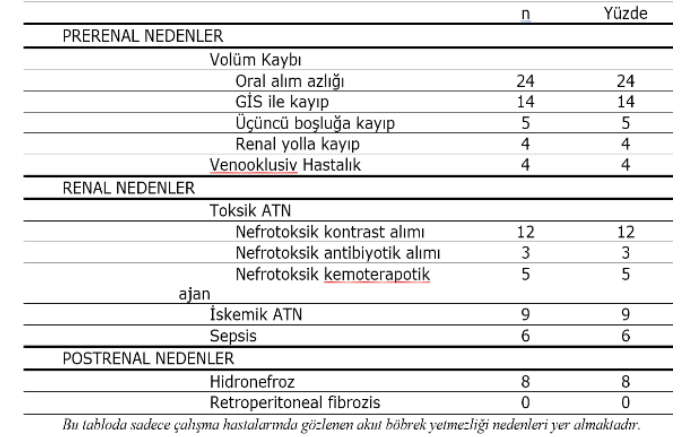

\section{TARTIŞMA}

Onkolojik hasta popülâsyonunda geriye dönük olarak gerçekleştirilen çalışmamız, tüm nedenlere bağlı böbrek yetmezliği gelişen 100 hastanın verileri incelenerek tamamlandi. Çalışmaya dahil edilen hastalarda en sık görülen kanser türleri sırasıyla akciğer, kolon ve meme kanseri idi ve katılımcıların \%74'ü erkekti. Bu çalışmada erkek cinsiyet oranı diğer çalışmalarda belirtilenlerden fazlaydı. Hastalarımızda gelişen en sık böbrek yetmezliği nedeni ise prerenal nedenlere bağliydı. Çalışmamız kesitsel bir çalışma olarak yapılandırıldığından ve örneklemlerin özel bir popülasyondan alınmasından dolayı komorbit hastalık oranları, hastalıkların cinsiyete göre dağılımları, malign hastalık sıklıkları genel popülâsyonla farkl111k gösteriyordu. Nitekim ülkemizde 2012 y1lı verilerine göre kanser insidans1 100000 'de erkeklerde 277, kadınlarda 188, ortalama 233 olarak bildirilmektedir (URL-1,2016. http://turkkanser.org.tr/news). Hasta popülasyonunun tümör tiplerine göre dağılımına bakıldığında en sık görülen 3 kanser tipi gelişmiş ülkelerde erkeklerde sırasıyla akciğer-bronş-trakea, prostat, kolorektal, kadınlarda meme, kolorektal, akciğer-bronştrakea kanserleri, az gelişmiş ülkelerde ise erkeklerde akciğer-bronş-trakea, karaciğer, mide, kadınlarda meme, akciğer-bronş-trakea, serviks uteri kanserleridir (https://gco.iarc.fr). Türkiye'deki kanser verilerinde erkeklerde sırasıyla akciğer-bronş-trakea, prostat, kolorektal, kadınlarda meme, tiorid, kolorektal kanserler ilk üç sırayı almaktadır (http://turkkanser.org.tr/). Çalışmamıza dahil edilen kanserli hastaların yaş ortalaması diğer literatür bilgileriyle $(60 \pm 12)$ uyuşuyordu (https://hsgm.saglik.gov.tr/tr/kanseristatistikleri/yillar/2014).

Genel popülasyonda ABY nedenleri iyi irdelenmiş ve dökümente edilmiştir. Ancak ABY epidemiyolojisi ile ilgili detaylı çalışmaların çoğu gelişmiş ülkelerde ve yeni akut böbrek hasarı tanım kriterlerinden önce yapılmıştır. Gelişmiş ülkelerde yapılan yakın bir çalışmada, mevcut hastalıklarının kanser olup olmamasına bakılmaksızın hastaneye $A B Y$ ile yatırılan hastalarda en s1k ABY nedeni olarak akut tubüler nekroz (ATN) ve prerenal hastalık bildirilmiştir (5). İspanya'da yapılan 748 böbrek yetmezlikli hastalarda bu araştırmada 13 tane üçüncü basamak hastane merkezindeki datalar incelenmiş ve ABY'nin en s1k nedeni \%45'lik bir oranla ATN olarak saptanmıştır (5). Prerenal nedenler \%21'lik oranla ikinci sırayı almıştır. Aynı makalede obstrüktif nefropatilerin oranı $\% 10$, glomerülonefritler veya vaskülitlerin oran $1 \% 4$, akut interstisyel nefritler $\% 2$ ve ateroemboli $\% 1$ olarak rapor edilmiştir. \%13 oranında ise kronik böbrek yetmezliği (KBY) zemininde gelişen ATN ve prerenal hastalık birlikteliğine rastlanmıştır (5). Yoğun bakım ünitelerinde yapılan çalışmalarda bu oranlar farklılık göstermektedir ve ATN sıklı̆̆ $1 \% 70$ 'lere kadar yükselmektedir (6). Az gelişmiş ülkelerde yapılan çalışmalarda prerenal nedenli ABY tüm ABY nedenleri arasında ilk sıradadır (2).

Onkolojik hasta popülasyonunda yapılan çalışmalarda ise böbrek yetmezliği oranları şu şekildedir; kanser nedeniyle sistemik kemoterapi alan 163,071 hastalık bir çalışmada hospitalize edilen hastaların 1/10'unda böbrek yetmezliği tespit edilmiştir (7) 5 yıllık takipte ABY insidansı en yüksek olan kanserler multiple myelom (\%26), mesane (\%19), lösemi (\%15) ve böbrek kanserleri olarak bildirilmiştir (https://www.uptodate.com). Sistemik tedaviyi izleyen 90 günlük periyotta ileri evre kanser, zeminde KBY olması ve DM birlikteliği ABY riskini artırıcı etmenler olarak izlenmiştir (7). Diğer çalışmalarda kritik hastalarda, (8) nefrektomi geçiren böbrek tümörlü hastalarda $\mathrm{ABY}$ riskinin arttığı gösterilmiştir (9) Ancak bu çalışmaların hiçbirinde böbrek yetmezliği alt grup analizleri yapılmamıştır. Yaptığımız çalışmada biz onkolojik hastalarda böbrek 
yetmezliği gelişme sıklığını \%15 olarak saptadik. Toplam 55 hastada prerenal, 37 hastada renal, 8 hastada postrenal nedenlere bağlı ABY gelişmişti. Daha detaylı datalar tablo 3'de verilmiştir. $\mathrm{Bu}$ oranlar gelişmekte olan ülke profiline daha çok uymaktadır. Gelişmiş ülkelerde genel popülasyonda $\mathrm{ABY}$ en sik renal nedenlere bağlıdır (5).

Onkolojik hastalarda vurgulanan diğer bir konu da kemoterapötik ajanların neden olduğu böbrek yetmezlikleridir. Klinik olarak böbrek yetmezliği asemptomatik kreatinin yüksekliğinden renal replasman tedavisine kadar gidebilen bir süreci içerebilir. Kemoterapotik ajanlar hem prerenal hem de renal nedenlerle $A B Y$ 'e neden olabilir. Renal nedenler daha çok tubüler toksik etkiye bağlıdır ve platin bazlı kemoterapötik ilaçlarla daha sik görülmektedir. Çalışmamızda kontrast ile gelişen nefropatilerin diğer nefrotoksik ajanlarla gelişen renal böbrek yetmezliklerini geride bıraktığı gözlenmiştir. Renal doz ayarlamaları ve daha az toksik kemoterapötiklerin seçilmesi ile bu ajanların nefrotoksik etkilerinden kaçınılmasına olanak sağlamıştır. Ama kontrastlı görüntülemelerin bu tarzda fazla alternatifleri bulunmamasi ve sıklıkla aynı hastalarda mükerrer kontrastlı tetkiklerin gerekliliği kontrast nefropati sıklığının yüksek kalmasına neden olmuştur.

Birçok gözlemsel çalışmada ABY gelişen kanserli hastalarda özellikle de renal replasman tedavisi gerekenlerde mortalite riski $\mathrm{ABY}$ gelişmeyen kanser hastalarına göre daha yüksek bulunmuştur $(6,8,10) \mathrm{KBY}$, kanser tedavisinin ve kanserin kendisinin s1k görülen bir komplikasyonudur. 4077 hastalık prospektif bir çalışmada onkolojik hastaların \%30'unda eGFR 45-59 $\mathrm{mL} / \mathrm{dak} / 1,73 \mathrm{~m}^{2} \% 8,3$ 'ünde de 45 $\mathrm{mL} / \mathrm{dak} / 1,73 \mathrm{~m}^{2}$ altında tespit edilmiştir (11) KBY mevcudiyetinin kanser hastalarında ölüm oranının artırıp artırmadığı tartışmalıdır (12). $\mathrm{Bu}$ çalışmada prerenal nedenlere bağlı ABY gelişen 5 hasta, renal nedenlere bağlı gelişen ABY 5 hasta yaşamını yitirmiştir. Bu oranlar renal nedenlere bağlı mortalitenin daha fazla olabileceğini akla getirmektedir.

Sonuç olarak onkolojik hastalarda da böbrek yetmezliği gelişimi mortalite oranını yükseltmektedir ve önlenebilir sebepleri tespit etmek bu hastaların daha uzun yaşamalarını sağlayabilir. Prerenal ve postrenal nedenleri iyi irdelemek ve saptamak ve bunları düzeltmek üzerinde durulması gereken iki büyük konu gibi durmaktadır. Genel popülasyon çalışmalarında daha düşük olan iskemik ATN gelişme sıklığ bizim çalışmamızda daha yüksek oranda gözlenmiştir.

\section{Conflict of interest:None}

\section{References}

1. Glassock, R.J. and Massry, S.G. Neoplasia Textbook of Nephrology. In: Glassock RJ, Massry SG eds. Williams and Wilkins, 3th ed Baltimore, 1996:1117-1123.

2. Erek E. Böbrek Yetersizliği. Editör Erek E., Nefroloji, 5. Bask1, İstanbul, Nobel Tip Kitapevleri, 2005:269-278.

3. Liangos O, Wald R, O'Bell JW, Price L, Pereira BJ, Jaber BL: Epidemiology and outcomes of acute renal failure in hospitalized patients: a national survey. Clin J Am Soc Nephrol 2006;1:43-51.

4. Cem S. Akut Böbrek Yetmezliği. Editörler; Nurol A, Melda D. Nefroloji, 2. Bask1. İstanbul, Karakter Color, 2008:257-276.

5. Darmon M, Ciroldi M, Thiery G, et al. Clinical review: specific aspects of acute renal failure in cancer patients. Crit Care 2006;10(2): 211.

6. Lahoti A, Kantarjian H, Salahudeen AK, et al. Predictors and outcome of acute kidney injury in patients with acute myelogenous leukemia or high-risk myelodysplastic syndrome. Cancer 2010;116(17):4063-8.

7. Kitchlu A, McArthur E, Amir E, et al. Acute Kidney Injury in Patients Receiving Systemic Treatment for Cancer: A Population-Based Cohort Study. J Natl Cancer Inst 2018;111(7):727-736

8. Libório $\mathrm{AB}$, Abreu $\mathrm{KL}$, Silva $\mathrm{GB} \mathrm{Jr}$, et al. Predicting hospital mortality in critically ill cancer patients according to acute kidney injury severity. Oncology 2011;80:160-6.

9. Cho A, Lee JE, Kwon GY, et al. Post-operative acute kidney injury in patients with renal cell carcinoma is a potent risk factor for new-onset chronic kidney disease after radical nephrectomy. Nephrol Dial Transplant 2011;26:3496-501.

10. Soares M, Salluh JI, Carvalho MS, et al. Prognosis of critically ill patients with cancer and acute renal dysfunction. J Clin Oncol 2006;24:4003-10.

11. Iff $S$, Craig JC, Turner R, et al. Reduced estimated GFR and cancer mortality. Am J Kidney Dis. 2014; 63:23-30.

12. Yang Y, Li HY, Zhou Q, et al. Renal Function and All-Cause Mortality Risk Among Cancer Patients. Medicine (Baltimore) 2016;95:e3728. 